\begin{tabular}{|c|c|c|c|}
\hline 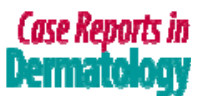 & $\begin{array}{l}\text { Case Rep Dermatol 2010;2:183-188 } \\
\text { DOI: } 10.1159 / 000321012\end{array}$ & $\begin{array}{l}\text { Published online: } \\
\text { November 6, } 2010\end{array}$ & $\begin{array}{l}\text { () } 2010 \text { S. Karger AG, Basel } \\
\text { ISSN } 1662-6567 \\
\text { www.karger.com/cde }\end{array}$ \\
\hline
\end{tabular}

\title{
Psoriatic Pseudobalanitis Circinata as a Post-Viral Koebner Phenomenon
}

\author{
Anna Zampetti ${ }^{a}$ Maria Gnarra ${ }^{a}$ Dennis Linder ${ }^{b}$ \\ Maria Donatella Digiuseppe ${ }^{c}$ Nicola Carrino $^{c}$ \\ Claudio Feliciani ${ }^{\mathrm{a}}$
}

aDepartment of Dermatology, Policlinico A. Gemelli, Università Cattolica del Sacro

Cuore, Rome, bepartment of Dermatology, University of Padova, Padova, and

'Department of Dermatology, Ospedale SS. Annunziata e Azienda Sanitaria

Locale, Taranto, Italy

\section{Key Words}

Psoriasis · Herpes simplex virus · Koebner phenomenon

\begin{abstract}
In the absence of any other lesions on the body, the diagnosis of localized genital psoriasis can be difficult, requiring further examinations including a biopsy. We report a case of psoriatic pseudobalanitis circinata triggered by a herpes virus infection, and we discuss the Koebner phenomenon and the therapeutic management of psoriasis of the genital area.
\end{abstract}

\section{Introduction}

Psoriasis is a common multifactorial skin dermatitis with a strong genetic background whose prevalence is estimated to be around $2-2.8 \%$ [1]. The most common type is the chronic en plaques psoriasis involving scalp, elbows and knees, but psoriatic lesions may be observed in any part of the body, including genitals. In this area, lesions may occur within a generalized form or as a localized form, in complete absence of any stage of the disease. The onset of genital psoriasis can be induced by local trauma and injury, but infections acting as a Koebner phenomenon (KPh) should also be considered. The diagnosis is not always easy to formulate since the clinical presentation is characterized by asymptomatic or light irritating thin red plaques with a well-defined edge, lacking the typical scale because of maceration [2]. The treatment of genital lesions deserves special care due to the high sensitivity of the thin genital skin and the increased absorption of topical agents, especially steroids. 


\begin{tabular}{|c|c|c|c|}
\hline $\begin{array}{l}\text { Cose Reports in } \\
\text { iellate. Lil }\end{array}$ & $\begin{array}{l}\text { Case Rep Dermatol 2010;2:183-188 } \\
\text { DOI: 10.1159/000321012 }\end{array}$ & $\begin{array}{l}\text { Published online: } \\
\text { November 6, } 2010\end{array}$ & $\begin{array}{l}\text { ○) } 2010 \text { S. Karger AG, Basel } \\
\text { ISSN } 1662-6567 \\
\text { www.karger.com/cde }\end{array}$ \\
\hline
\end{tabular}

In this report we describe a case of localized glans psoriasis induced as KPh by a herpes simplex virus (HSV) infection presenting as a pseudobalanitis circinata, and we discuss the diagnostic process, the pathogenesis of $\mathrm{KPh}$ and the therapeutic management of psoriasis of the genital area.

\section{Case Report}

A 45-year-old man, at that time not engaged in a steady relationship, came to our outpatient service for the sudden onset of painful grouped vesicles of the glans (fig. 1). The patient did not refer any remarkable past disease, but he reported a granduncle affected by psoriasis with regard to the family history. The clinical diagnosis of a HSV skin infection was confirmed by the serologic positivity for HSV2 IgM and IgG antibodies. We tested the patient for other sexually transmitted diseases: syphilis, HIV and hepatitis B and C, and the outcome was negative. The patient was given a one-week topical treatment with acyclovir three times daily and the lesions resolved completely. One month later, the patient returned to our clinic reporting the outbreak of new only slightly itching lesions in the same area, 10 days after having finished the topical treatment. A second cycle of topical antiviral treatment had showed no effect. No sexual intercourse was referred since the onset of HSV infection. The new lesions presented now as pseudo-anular circinate whitish flat papules (fig. 2). The patient did not report any symptoms of urethritis, gastrointestinal disorders or arthritis, no oral aphthae were observed; laboratory tests allowed to rule out any ongoing infection. A biopsy was performed and histology showed acanthosis and papillomatosis of the epidermis with parakeratosis, microabscesses of neutrophils but no spongiosis; enlarged capillaries were present at the apex of dermal papillae, and the diagnosis of psoriasis could be made (fig. 3 ). Following a treatment with topical tacrolimus $0.1 \%$ ointment applied once a day for 3 weeks the lesions resolved completely.

\section{Discussion}

In absence of any other lesions on the body surface, the diagnosis of localized genital psoriasis is not easy to formulate, and many other disorders should be considered in the diagnostic process such as Reiter's syndrome or candida balanitis, seborrheic dermatitis, lichen planus, syphilis or contact dermatitis. When the clinical history and presentation cannot clearly orientate, histology may be needed, as in our case. The onset of psoriatic lesions induced de novo after a HSV infection can be regarded as a $\mathrm{KPh}$. The proliferative and the immune response patterns in psoriasis have been recognized for their similarity to the wound response: the development of inflammatory psoriasis plaques is triggered by mechanical skin trauma, as well as infections [3]. When the KPh takes place, psoriatic lesions usually appear 7-14 days after the triggering event. The precise pathomechanism of the KPh still remains unclear [4].

Currently, there are several lines of evidence suggesting dysregulation of the innate immune system in psoriasis. Activated dendritic cells are increased in early psoriatic lesions through complexes of the antimicrobial peptide LL-37 cathelicidin and DNA in a Toll-like receptor 9-dependent manner. Host DNA is then turned in a proinflammatory stimulus breaking immunologic tolerance and followed by migration of dendritic cells to lymph nodes, activation of T cells and affluence of predominantly Th17 cells to dermis and epidermis. A complex cytokine network, in which IL-17, IL-22 and TNF-alpha are the most important mediators, is then induced and it maintains keratinocyte proliferation. The available data support the notion that psoriasis is probably an autoimmune-related disease characterized by chronic inflammation in the absence of currently known infectious agents or antigens [5]. Specifically, the relationship between psoriasis and viral agents is still far to be clarified. In patients with AIDS in whom 
circulating CD4+ T cells are depleted, the paradoxical exacerbation of psoriasis could be explained by the virus itself or by one or more of the associated opportunistic infections [6]. A potential role as autoantigen or opportunistic agent has been suggested for HPV 5 detected in scrapings of lesional skin in approximately $90 \%$ of a large series of psoriatic patients [7]. Recent studies have demonstrated that HSV can also act through the expression of molecules called PRINS (Psoriasis-susceptibility-Related RNA Gene Induced by Stress) in the epidermis. PRINS belongs to the group of recently described mRNA-like noncoding RNA genes which are spliced, polyadenylated mRNA molecules containing a high density of stop codons and lacking an extensive open reading frame. Also induced by UVB and trauma, they function as a regulatory RNA, playing a protective role in cells exposed to stress and contributing to psoriasis susceptibility [8]. Finally, Raychaudhuri et al. have demonstrated that in stressed basal keratinocytes, upregulation of nerve growth factor, which has a wide array of biological actions on inflammation, immune system and cell proliferation, is an early event and precedes epidermotropism of $\mathrm{T}$ lymphocytes in the $\mathrm{KPh}$ [3]. For its promotion of cutaneous innate host defences against virus through Toll-like receptor expression and the block of inflammatory cytokine release, topical tacrolimus, a calcineurin inhibitor, is an effective treatment of psoriasis. A further mode of action shared with other calcineurin inhibitiors may run over the peroxisome proliferator-activated receptors (PPARs): it has been recently shown that PPAR $\beta / \delta$ causes a psoriasis-like skin disease in mice and that PPAR $\delta$ enhances keratinocyte proliferation in psoriasis [1]. On the basis of our and other observations, one may hypothesize that tacrolimus may prove an effective and well tolerable, albeit yet expensive alternative to topical steroids for the treatment of psoriasis and that the use of this substance might soon be proven the treatment of first choice in some critical body areas, such as the face or genitals. Potential side effects, such as skin atrophy, and consequently pain during sexual intercourse, may be avoided by choosing this drug, and a rapid resolution of the psoriatic genital lesions with good tolerability may be observed as it was in our case [9]. 


\begin{tabular}{l|l|l|l} 
Cose Reports in & $\begin{array}{l}\text { Case Rep Dermatol 2010;2:183-188 } \\
\text { DOI: } 10.1159 / 000321012\end{array}$ & $\begin{array}{l}\text { Published online: } \\
\text { November 6, 2010 }\end{array}$ & $\begin{array}{l}\text { O 2010 S. Karger AG, Basel } \\
\text { ISSN 1662-6567 } \\
\text { www.karger.com/cde }\end{array}$ \\
\hline Deillate.0.1) & &
\end{tabular}

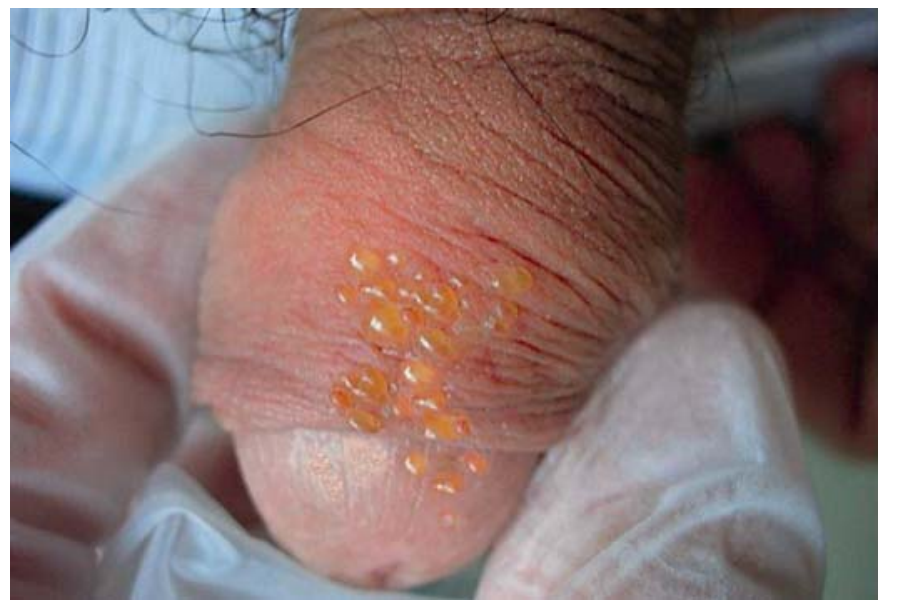

Fig. 1. Groups of painful vesicles of the glans were observed in a 45-year-old man who presented a serologic positivity for HSV2 IgM antbibodies, confirming an acute infection.

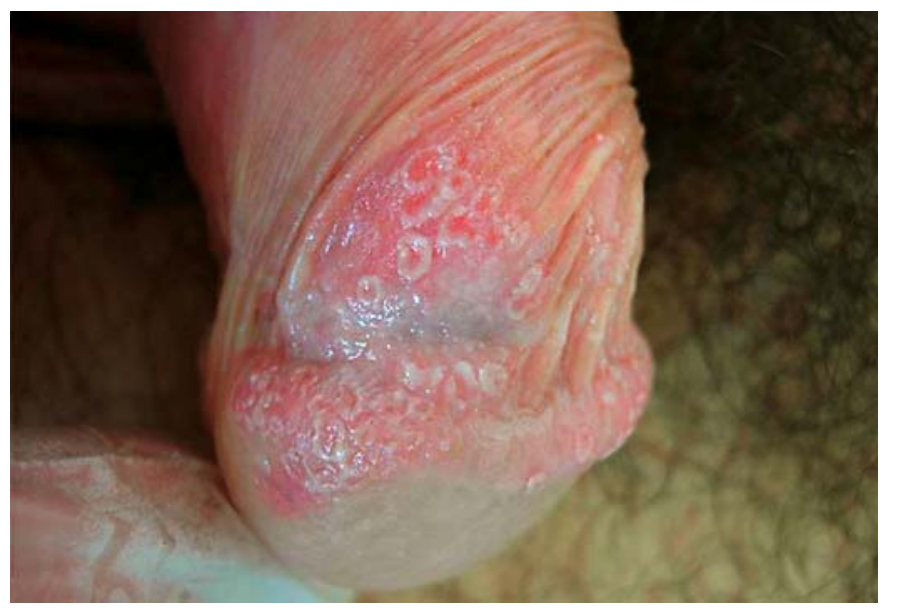

Fig. 2. After 1 month, new lesions presenting as pseudo-anular circinate whitish flat papules were observed. This histology confirmed the presence of psoriasis. 


\begin{tabular}{|c|c|c|c|}
\hline $\begin{array}{l}\text { Case Reports in } \\
\text { Lillatioil }\end{array}$ & \begin{tabular}{|l} 
Case Rep Dermatol 2010;2:183-188 \\
DOI: 10.1159/000321012
\end{tabular} & $\begin{array}{l}\text { Published online: } \\
\text { November 6, } 2010\end{array}$ & $\begin{array}{l}\text { () } 2010 \text { S. Karger AG, Basel } \\
\text { ISSN } 1662-6567 \\
\text { www.karger.com/cde }\end{array}$ \\
\hline
\end{tabular}

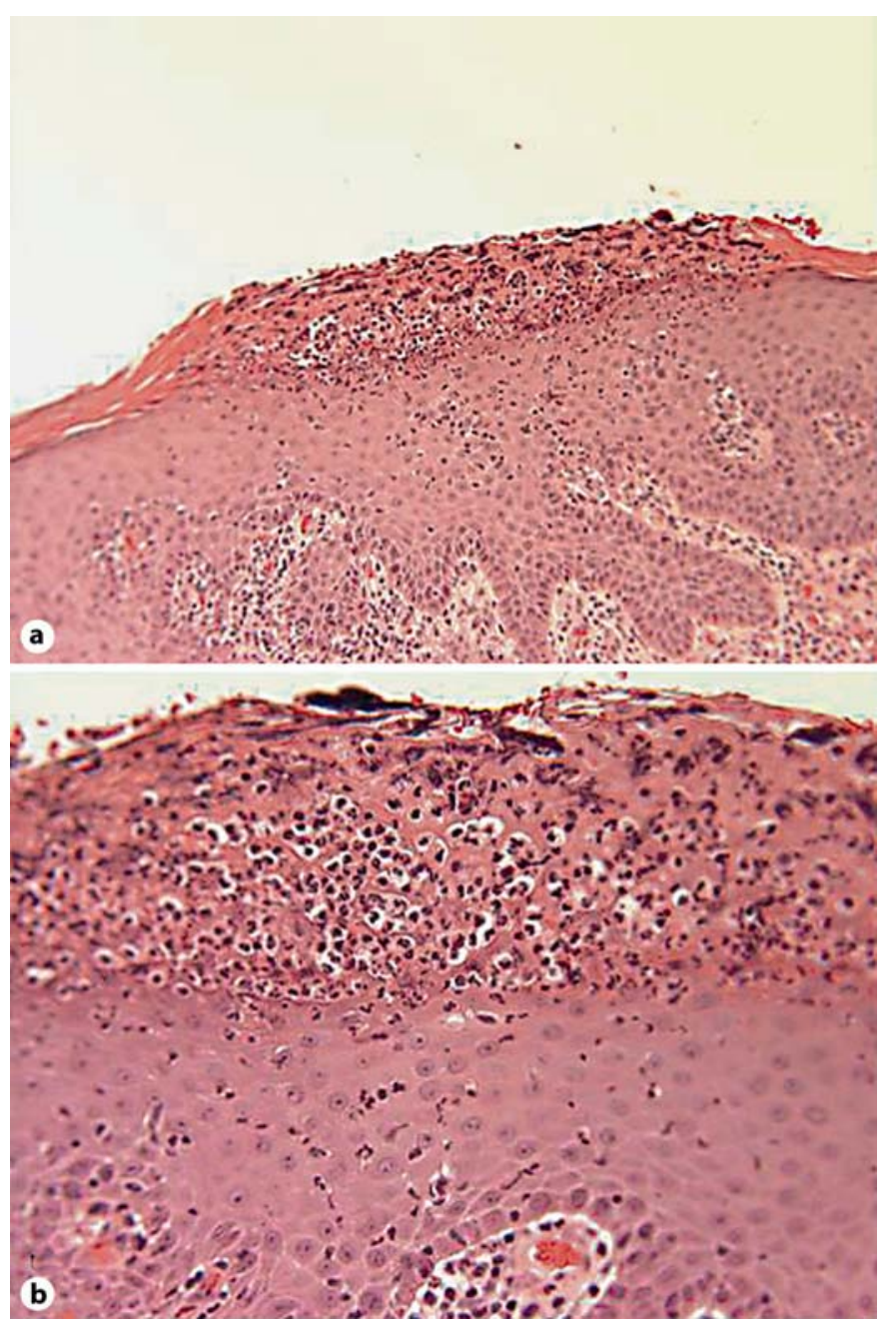

Fig. 3. The histology showed acanthosis and parakeratosis of the epidermis with absence of the granular layer (a), along with an inflammatory infiltrate of polymorphonuclear leucocytes in the dermis and epidermis (b).

\section{References}

1 Gudjonsson JE, Elder JT: Psoriasis: epidemiology. Clin Dermatol 2007;25:535-546.

2 Meeuwis KA, de Hullu JA, de Jager ME, Massuger LF, van de Kerkhof PC, van Rossum MM: Genital psoriasis: a questionnaire-based survey on a concealed skin disease in the Netherlands. J Eur Acad Dermatol Venereol 2010. [Epub ahead of print].

3 Romanowska M, Reilly L, Palmer CN, Gustafsson MC, Foerster J: Activation of PPARbeta/delta causes a psoriasis-like skin disease in vivo. PLoS One 2010;5:e9701.

-4 Raychaudhuri SP, Jiang WY, Raychaudhuri SK: Revisiting the Koebner phenomenon: role of NGF and its receptor system in the pathogenesis of psoriasis. Am J Pathol 2008;172:961-971.

5 Clark RA: Skin-resident T cells: the ups and downs of on site immunity. J Invest Dermatol 2010;130:362-370.

6 Fry L, Baker BS: Triggering psoriasis: the role of infections and medications. Triggering psoriasis: the role of infections and medications. Clin Dermatol 2007;25:606-615. 
7 Favre M, Orth G, Majewski S, Baloul S, Pura A, Jablonska S: Psoriasis: a possible reservoir for human papillomavirus type 5 , the virus associated with skin carcinomas of epidermodysplasia verruciformis. J Invest Dermatol 1998;110:311-317.

8 Sonkoly E, Bata-Csorgo Z, Pivarcsi A, Polyanka H, Kenderessy-Szabo A, Molnar G, Szentpali K, Bari L, Megyeri K, Mandi Y, Dobozy A, Kemeny L, Szell M: Identification and characterization of a novel, psoriasis susceptibility-related noncoding RNA gene, PRINS. J Biol Chem 2005;280:24159-24167.

9 Simpson D, Noble S: Tacrolimus ointment: a review of its use in atopic dermatitis and its clinical potential in other inflammatory skin conditions. Drugs 2005;65:827-858. 